\title{
Friend or foe? Customer engagement's value-based effects on fellow customers and the firm
}

Article

Accepted Version

Creative Commons: Attribution-Noncommercial-No Derivative Works 4.0

Clark, M. K., Lages, C. R. and Hollebeek, L. D. (2020) Friend or foe? Customer engagement's value-based effects on fellow customers and the firm. Journal of Business Research, 121. pp. 549-556. ISSN 0148-2963 doi:

https://doi.org/10.1016/j.jbusres.2020.03.011 Available at https://centaur.reading.ac.uk/89681/

It is advisable to refer to the publisher's version if you intend to cite from the work. See Guidance on citing.

To link to this article DOI: http://dx.doi.org/10.1016/j.jbusres.2020.03.011

Publisher: Elsevier

All outputs in CentAUR are protected by Intellectual Property Rights law, including copyright law. Copyright and IPR is retained by the creators or other copyright holders. Terms and conditions for use of this material are defined in the End User Agreement.

www.reading.ac.uk/centaur 
Central Archive at the University of Reading

Reading's research outputs online 


\title{
Friend or foe?
}

\section{Customer engagement's value-based effects on fellow customers and the firm}

\begin{abstract}
Customer engagement (CE) research has rapidly developed in recent years, with insight being gleaned in such areas as CE conceptualization, valence, measurement, and theoretical associations. However, despite the development of understanding of CE's impact on the focal customer (e.g. by cultivating his/her brand attachment/loyalty), much less remains known regarding CE's effects on other actors, particularly on multiple actors simultaneously. Based on the premise that differing actors tend to have different goals/interests, as advanced in stakeholder theory, we deduce that positive/negative CE can yield differing perceived valuebased effects across actors. To address this issue, we examine the particular case of positive/negative CE's value-creating/eroding effects as perceived by the actors of fellow customers and the firm, which we classify in a multi-actor typological framework. After introducing and discussing the typology, we conclude by outlining key implications that arise from this research, limitations, and avenues for further research on CE's multi-actor effects.
\end{abstract}

Keywords: Customer engagement, stakeholder theory, value, multi-actor effects, typology. 


\section{Friend or foe? \\ Customer engagement's value-based effects on fellow customers and the firm}

\section{Introduction}

In recent years, the customer engagement $(\mathrm{CE})$ concept has seen rapidly growing scholarly interest and debate (Harmeling et al., 2017), as illustrated by the Marketing Science Institute's inclusion of the concept as a key research priority since 2010 (e.g. MSI, 2010, 2018). CE, which reflects "a customer's motivationally driven... investment of ...operant resources (including cognitive, emotional, behavioral, and social knowledge/skills) and operand resources (e.g. equipment) into brand interactions" (Kumar et al., 2019, p. 141), has found particular applicability in contexts characterized by high interactivity, including services and Web 2.0 (and beyond) applications (e.g. Islam et al., 2019), where it has been acclaimed to yield heightened firm performance (Brodie et al., 2011).

To date, scholars have focused on defining and measuring CE, and deriving insight into its contextual dynamics, drivers, and outcomes (Baldus et al., 2015; Kumar et al., 2010). The majority of published research explores CE's consequences on the focal customer him/herself (i.e., the engagement subject; Hollebeek, 2011), including the development of customer satisfaction or loyalty (e.g. Harrigan et al., 2018). Fewer studies explore CE's consequences on other actors, typically the firm (e.g. in terms of financial performance; Kumar et al., 2010; Pansari \& Kumar, 2017) or its representatives (e.g. employees; Kumar \& Pansari, 2016).

Consequently, understanding of CE's effects on others lags behind, particularly on multiple actors concurrently, thereby posing an important research gap. Given service systems' connected nature, we expect CE to affect a range of stakeholders simultaneously (Vargo \& Akaka, 2012), thus meriting further research. Specifically, a pressing need exists to explore CE's effects on multiple actors, particularly those who interact directly with the focal customer (e.g. fellow customers/the firm), as explored in this paper. Here, the focal customer is (s)he who interacts with the brand, which can in turn affect the offering's other or fellow customers, particularly in multi-customer 
contexts characterized by customer-to-customer interactivity (Libai et al., 2010). Examples include online/offline group-based (e.g. educational, gym, cooking) classes, excursions/tours, brand communities, social media, and other shared servicescapes (e.g. libraries, schools, hospitals, train stations, airports, hotel-lobbies, public transportation, restaurants, rest homes, cinemas; Ekpo et al., 2015; Tombs \& McColl-Kennedy, 2003; Anderson et al., 2001).

We posit that a customer's engagement tends to yield differing cross-stakeholder effects, given their differing interests and perspectives, as formulated in stakeholder theory (Freeman, 1984; Donaldson \& Preston, 1995). As stated, we explore CE's effects on the specific stakeholders of fellow customers and the firm. Our analyses recognize CE's positive (e.g. helping) versus negative (e.g. harming) valence towards these actors (Herman \& Miall, 1990), thereby extending existing CE valence-based research (e.g. Heinonen, 2018).

Moreover, while the $\mathrm{CE} /$ perceived value interface has received prior attention (Kumar et al., 2010; Hollebeek, 2013), limited insight exists into CE's value-creating/depleting effects on multiple actors simultaneously, as explored in this paper. As stated, we address positive/negative CE's value-based effects on fellow customers and the firm in multi-customer contexts (LeroiWerelds, 2019; Curth et al., 2014), thus focusing on this particular stakeholder subset (Covell, 2005).

Our primary purpose is to develop and classify positive/negative CE's value-creating/depleting effects on fellow customers and the firm in a typology, which represents a widely-used classificational framework in organizational and marketing research (Hambrick, 1984; Santoro et al., 2018). This study makes two main contributions. First, extending Kumar and Pansari's (2016) view of (employee) engagement's effect on other actors (i.e., customers), we explore CE's specific other actor-perceived effects. As existing research largely addresses CE's effects on the focal customer him/herself, as outlined, we contribute to the literature by exploring CE's value-based effects on the actors of fellow customers and the firm in multi-customer contexts (Curth et al., 
2014; Sreejesh et al., 2017). By examining CE's multi-actor effects, we elucidate specific connected ecosystem actors' engagement, which is subject to growing interest (Brodie et al., 2016; Mitchell \& Clark, 2019). Ecosystems comprise resource-integrating actors that are connected by shared institutional logics and mutual value creation through service exchange (Vargo \& Akaka, 2012, p. 207). Following Hult et al. (2011, p. 48), we equate actors and stakeholders. Given CE's midrange theoretical nature, our contributions exist at this level in the theoretical hierarchy (Vargo \& Lusch, 2017, p. 50).

Second, we develop a typological framework of CE's value-based effects, which classifies and elucidates CE's perceived value-creating or -eroding effects or consequences on fellow customers and the firm (Freeman, 1999; Herman \& Miall, 1990). Given our exploration of positive/negative $\mathrm{CE}$ and the inclusion of three actors (i.e., focal customer, fellow customer, firm), the typology proposes eight $\left(2^{3}\right)$ possible CE value-based effects for these actors. Given CE's capacity to create value for one actor, but deplete value for another, we identify the asymmetric nature of its value-based cross-actor effects (Edvardsson et al., 2011). Moreover, though positive (negative) CE's favorable (adverse) effects have been documented (Bowden et al., 2017), our typology extends existing insight by identifying positive CE's potentially unfavorable effects on particular stakeholders, and vice versa.

The next sections unfold as follows. In section 2, we review pertinent theoretical foundations for our analyses, followed by a review of CE and perceived value literature. In section 3, we first synthesize the development of typologies in marketing/organizational research, followed by the introduction of our typology of CE's value-based effects. In section 4, we conclude with a discussion of key implications, limitations, and further research avenues that emanate from this research.

\section{Literature review}


Below, we review important theoretical foundations to this research that reside in stakeholder theory, followed by a review of $\mathrm{CE}$ and perceived value research. Collectively, these underpin the typology's development in section 3.

\subsection{Stakeholder theory's differing cross-actor effects}

Developed in the 1980s, stakeholder theory is a management and business ethics perspective that recognizes that multiple actors are affected by a stakeholder's (typically, the firm's) actions, including employees, customers, suppliers, creditors, competitors, government, etc. (Freeman, 1999). It acknowledges that different stakeholders - defined as individuals/groups who can affect or are affected by a central stakeholder (Freeman (1984, p. 46) - can and often do have differing interests, expectations, and responsibilities, thus influencing their service system-based engagement and its outcomes (Hult et al., 2011).

Taking a firm perspective, stakeholder theory traditionally assumes that the firm or its agents (e.g. managers) hold a level of authority that other stakeholders lack (Hult et al., 2011). However, here we adopt the focal customer as central stakeholder (Curth et al., 2014). While a customer role does not entail high formal authority per se, informally, customer clout can manifest through buyer bargaining power (i.e. clout over the firm; Porter, 1980) or opinion leadership (i.e. clout over fellow customers; Beckers et al., 2014), revealing CE's key links to these actors. Conversely, most firms also have rules to guide customer/brand interactions (e.g. codes-of-conduct), illustrating their potential effect on the focal customer (Hillebrand et al., 2015). We hence select this particular actor subset for further exploration.

Stakeholder theory recognizes that actors may have diverging or conflicting agendas, interests, and value-creating objectives (Hult et al., 2011). For example, while customers desire high-quality, low-priced offerings, firms may strive to offer lower-quality products to optimize profits (Freeman, 1999). Therefore, while one actor may view an interaction to create value, another may see it as value-depleting. Likewise, in our multi-customer context, a focal customer's brand engagement 
can be perceived as value-generating by one stakeholder (e.g. the firm: through the client's repurchase), but value-eroding by another (e.g. fellow customers: due to the individual's dominance), whether intended or unintended (Hillebrand et al., 2015; Hollebeek et al., 2016). Our subsequent analyses rest on the premise that a customer's engagement can have differing valuebased cross-actor effects, as inferred from stakeholder theory.

From a business ethics perspective, stakeholder theory also examines the justification for and legitimacy of stakeholders' actions. The focal customer may engage in varying levels of moral or ethical behavior vis-à-vis fellow customers and/or the firm (e.g. by manipulating or unduly influencing these actors), thereby positively or negatively impacting one or both of these (Hillebrand et al., 2015). For example, focal customers who unfairly complain about a product/service, only in an attempt to receive a refund, are adversely affecting the firm (Berry \& Seiders, 2008). In the typology (section 3), we further detail scenarios of the focal customer's varying moral/ethical behavior and its effects on these actors.

\subsection{Customer engagement}

CE research has seen exponential growth in the last decade (Harmeling et al., 2017). In Table 1, we offer several CE definitions, from which we make the following observations. First, the table's right column highlights CE's customer/brand focus, corroborating our observed paucity of insight into CE's effects on other ecosystem actors (Corus \& Ozanne, 2012).

Second, though the definitions reveal CE's debated conceptualization, there are two broad areas of agreement, including its interactive core and multidimensional nature (Roy et al., 2018; Vivek et al., 2014). Regarding interactivity, CE reflects customers' resource investments in their brand/firm interactions, with more extensive operant (e.g. skill-based) and/or operand (e.g. equipment-based) resource investments denoting higher engagement (Kumar et al., 2019; Hollebeek et al., 2019). Here, interaction denotes “mutual or reciprocal action or influence," which impacts actor-perceived value (Vargo \& Lusch, 2016, p. 9). 
Reflecting CE's dimensionality, its constituent operant resource investments comprise customers' cognitive (thought-based), emotional (affective), and behavioral (activity-based) investments in their brand interactions, thus reflecting the concept's multidimensional nature (Harrigan et al., 2018; Calder et al., 2009). However, some authors limit their view to behavioral CE (Verleye et al., 2014; Ho et al., 2020), including through direct (i.e. purchases) and indirect contributions (e.g. referrals, online influence, feedback; Kumar et al., 2019; Pansari \& Kumar, 2017). In line with the latter view, we focus on behavioral CE, which we recognize to have important underlying cognitive and emotional foundations (Fitzmaurice, 2005).

\section{Insert Table 1 about here}

Third, Table 1 indicates that while the majority of published research centers on positive, brand-supporting CE, an emerging sub-stream recognizes the concept's negative valence that is conventionally viewed to yield adversarial outcomes (e.g. brand dilution; Juric et al., 2016). As engagement originates outside marketing, we reviewed the literature in related disciplines (e.g. organizational behavior, educational psychology), to explore their use of engagement's valence (Brodie et al., 2011). We found that these, similar to marketing, focus on positive engagement, but with some attention reserved for negative engagement. For instance, in educational psychology, negative student engagement is exemplified by absenteeism, keeping other students from working, or deliberate underperformance at school (Elmore \& Huebner, 2010). Likewise, in organizational behavior, negative employee engagement can be expressed by spreading negative word about the organization or jealousy at work (O’Connor \& Crowley-Henry, 2019; Andiappan \& Dufour, 2018).

Extending these ideas, Hollebeek and Chen (2014) coin CE's positive/negative valence, similar to cocreation/destruction (Echeverri \& Skålén, 2011). However, despite budding insight, scholarly understanding of positive/negative CE and its impact on other actors' outcomes remains tenuous, as explored further in section 3. Moreover, while positive (negative) CE's favorable 
(adverse) effects have been discussed (e.g. Bowden et al., 2017), our typology incorporates positive CE's potentially unfavorable effects on focal stakeholders, and vice versa. Finally, though some authors identify neutral, in addition to positive/negative engagement (Brodie et al., 2013), our analyses center on more polar positive/negative $\mathrm{CE}$, which yield greater theoretical richness.

\subsection{Perceived customer value}

The (perceived) customer value concept became mainstream in the 1990s (e.g. Woodruff et al., 1997; Slater, 1997). Since then, it has found applications in numerous contexts, including consumer durables, fast-moving consumer goods, and services. As an important driver of consumer decision-making, perceived value has been demonstrated to favorably affect firm outcomes, including by boosting sales and competitive advantage (Woodruff, 1997; Holbrook, 1994).

Zeithaml (1988, p. 14) defines customer value as a customer's "overall assessment of the utility of a product based on perceptions of what is received and what is given," reflecting the customer's inherent cost/benefit trade-off (Cronin, 2016). Here, costs comprise both monetary (e.g. price) and non-monetary (e.g. time) aspects. Value arises from consumers' resource-integrating processes, where they assimilate resources to create value, either for themselves or salient others (Leroi-Werelds, 2019; Grönroos \& Ravald, 2011; Peters et al., 2014).

Despite the literature's focus on value creation, we observe a growing recognition of value depletion or erosion (e.g. Smith, 2013), which entails the destruction of customer-perceived value, up to and including the point where it turns negative (e.g. due to the progressive removal of perceived benefits; Zeithaml, 1988). While in some cases, value depletion transpires unintentionally (e.g. firms striving - but failing - to satisfy customers), in others stakeholders purposely design other-actor perceived value depletion (e.g. by withholding benefits, raising costs, or setting them up to fail), as recognized in stakeholder theory (Hillebrand et al., 2015). Our typology, which is introduced in section 3 , incorporates both scenarios. 
Relatedly, stakeholder theory views the nature, intent, and focus of actors' value-creating aims and processes to differ, as discussed. Therefore, while an actor's (e.g. customer's) resource investments made in an interaction [i.e. engagement] may create value for one actor, it can erode value for another. That is, CE's value-based effects tend to be asymmetric across actors (Edvardsson et al., 2011). Though existing research has linked CE and perceived value (e.g. Kumar et al., 2010), limited insight exists into CE's value-based effects on multiple actors simultaneously, as explored further in section 3.

\section{Typology of CE's value-based effects}

Building on our review, we next introduce our typology of CE's value-creating/depleting effects on fellow customers and the firm, thus focusing on this particular actor subset. As stated in the Introduction, the typology has prime applicability in multi-customer settings that feature the focal customer's interactivity with fellow customers and the firm. In section 3.1, we outline key principles underlying typological development, followed by the introduction of our typology of CE's value-based effects in section 3.2.

\subsection{Typological development principles}

Typologies are a widely-used classificational approach in (marketing) strategy to better understand the categories inherent in specific phenomena-of-interest (Hambrick, 1984). Doty and Glick (1994, p. 233) offer three criteria for typological development that we discuss below.

First, typologies provide abstract, holistic configurations of specific phenomena, including ideal types or theoretical types that might exist (vs. actually exist per se). As "empirical examples of [some] ideal-type[s] are...very rare or non-existent" (Doty \& Glick, 1994, p. 233), typologies exhaustively include even sporadic classificational categories (Hunt, 1983). Matching this criterion, our typology comprehensively covers positive/negative CE's eight value-based effects on fellow customers and the firm. Thus, rather than classifying individuals based on salient traits 
(e.g. Kozinets, 1999), we categorize CE's particular value-based outcomes for our chosen actor subset (see Herman \& Miall, 1990; Gelbman, 2016).

Second, typological development should establish relationships among its key constituents (Doty \& Glick, 1994, p. 234). Fitting this criterion, our typology relates CE and its positive/negative value-based effects on fellow customers and the firm. For each typological element, a specific associative pattern exists (e.g. positive CE that transpires to benefit/harm fellow customers and/or the firm, respectively), as shown in Figure 1.

Third, falsifiability implies that typological predictions must be testable and subject to disconfirmation (Doty \& Glick, 1994, p. 234). While our focus is on comprehensive classification, our typological constituents can be tested or compared to one another (e.g. via cross-group analysis), thus permitting their falsifiability in future empirical research (see section 4.3).

\subsection{Typology}

Our typology classifies positive/negative CE's value-based effects on fellow customers and the firm. To develop the typology, we began by examining the focal customer's engagement, where positive (negative) engagement is intended to benefit (harm) one or both of these actors (Bowden et al., 2017). We next considered the range of outcomes of the focal customer's positive/negative $\mathrm{CE}$ on fellow customers and the firm, resulting in a typology of all possible (i.e., $2^{3}=8$ ) combinations of CE/value-based effects (see Fig. 1; Plutchik, 1980).

Above (below) the horizontal dashed line in Fig. 1, four scenarios are incorporated that reflect the focal customer's positive engagement (sections 3.2.1 to 3.2.4), followed by four sections centering on his/her negative engagement (sections 3.2.5 to 3.2.8). In each of the typology's components, the focal customer's positive/negative engagement is stated at the relevant petal's base, with its pertinent value-based effects on fellow customers and the firm shown in the petal's upper part.

\section{Insert Fig. 1 about here}




\subsubsection{Firm-impeding customer assistance}

CE's first value-based effect of firm-impeding customer assistance occurs when the focal customer's positive brand engagement has a favorable value-based effect on fellow customers, but a negative effect on the firm (see \#1: Fig. 1), in line with stakeholder theory's asymmetric actorbased effects (Hult et al., 2011). For example, a focal knowledgeable customer may help a fellow customer (e.g. through an online Apple-based assistance forum), reflecting her positive engagement. The fellow customer requires a new part, for which Apple would charge a premium.

However, given her extensive brand knowledge, the focal customer advises the fellow customer to purchase a more affordable substitute part through Alibaba to fix the problem. Therefore, the focal customer's positive brand engagement - as reflected by her ownership of the brand's product, extensive brand knowledge, and helping behavior - creates value for the fellow customer (i.e., by receiving an inexpensive solution). However, it simultaneously erodes value for the firm (i.e., by losing out on a sale). This CE valence-based effect is important, as it refines the literature's prevailing assumption that positive CE (e.g. through customers' brand-related contributions or helping behavior) will necessarily improve firm outcomes (Xie et al., 2008).

\subsubsection{Firm-benefiting, counter-productive customer assistance}

CE's second value-based effect of firm-benefiting, counter-productive customer assistance reflects the focal customer's positive brand engagement that negatively impacts fellow customerperceived value, while positively affecting the firm (see \#2: Fig. 1), thus further illustrating CE's asymmetric value-based effects (Edvardsson et al., 2011).

In social exchange theory, customers are predicted to reciprocate positive thoughts, feelings and behaviors toward a brand upon receiving specific benefits from the brand relationship (Blau, 1964; Kim et al., 2019). For example, pupils of a school with small class sizes and high levels of personal attention may widely rave about the service, reflecting their brand-related satisfaction and positive engagement. However, as the focal customer's recommendations are likely to attract new 
pupils, fellow customer (i.e., pupil)-perceived value is likely to wane (e.g. due to growing class sizes). The school however benefits (e.g. through growth). Interestingly, the focal customer's service-endorsing behavior may in time erode his/her own offering-related perceived value, illustrating CE’s potential unintended consequences (Hollebeek et al., 2016).

\subsubsection{Customer citizenship behavior}

CE's third value-based effect, customer citizenship behavior (see \#3: Fig. 1) is defined as customers' discretionary "voluntary extra-role behavior" that benefits the firm (Bartikowski \& Walsh, 2011, p. 39). As stated, social exchange theory predicts customers to reciprocate favorable brand/firm-related experiences (Blau, 1964), including through referrals or helping behaviors. Customer citizenship behavior thus reflects the focal customer's positive brand engagement.

In this value-based effect, the focal customer's positive engagement transpires favorably for fellow customers and the firm, thereby creating a win-win for both (Freeman, 2010). For example, CE's positive effect on fellow customers can transpire through their appreciation of the focal customer's referral, which also benefits the firm (e.g. by attracting new customers). Therefore, this CE value-based effect differs from firm-impeding customer assistance (section 3.2.1), which while sharing the focal customer's positive engagement and favorable effect on the fellow customer, backfires by eroding firm value.

\subsubsection{Pro-brand, existing loyalty-shifting behavior}

CE's next value-based effect of pro-brand, existing loyalty-shifting behavior reveals the focal customer's positive engagement that transpires negatively for fellow customers and the firm (see \#4: Fig. 1). For example, elderly customers who purchase and recommend iPhone 11 display favorable brand engagement. In social identity theory, consumers are predicted to derive positive self-esteem from their brand relationships, while attributing negative characteristics to other groups, particularly ones perceived as unattractive (Tajfel, 2010). If other (e.g. younger) customers view the brand's older clientele to undesirably affect their own social identity when using the 
product, they may migrate to other brands as a result of the focal customer's positive, pro-brand engagement (Lam et al., 2010).

In this CE value-based effect, the focal customer's positive engagement thus boomerangs by negatively impacting fellow customers (e.g. by removing an otherwise desirable brand from their consideration set; Wu \& Rangaswamy, 2003). It also adversely affects the firm (e.g. lost sales), revealing a symmetric value-based effect on both actors (Edvardsson et al., 2011).

\subsubsection{Firm-impairing, unintended customer assistance}

In this and the following sub-sections, we discuss CE's value-based effects that reveal the focal customer's negative engagement (Juric et al., 2016). Here, we introduce firm-impairing, unintended customer assistance, which reflects the focal customer's negative engagement that positively affects fellow customer-perceived value, while adversely impacting that of the firm (see \#5: Fig. 1; Beckers et al., 2018), thus again illustrating CE's asymmetric value-based effects.

In regulatory focus theory, the focal customer may emphasize the pursuit of gains or aspire the accomplishment of ideal goals, even to the point of disadvantaging others (Higgins, 2012). For example, a focal Zumba customer may dissuade fellow customers from attending the class, only to reduce in-class crowding (Berry \& Seiders, 2008), which may lead class numbers to fall below capacity. The firm may then introduce complimentary passes to raise class attendance, thus benefiting fellow customers and defying the focal customer's intent. The firm, however, loses out on revenue owing to the focal customer's negative brand engagement expressed to fellow customers, which is morally questionable as it does not reflect his/her true brand-related sentiment. Consequently, the firm's brand can also be diluted (Keller \& Sood, 2003).

\subsubsection{Firm-aiding customer jealousy prevention}

In firm-aiding customer jealousy prevention (see \#6: Fig. 1), the focal customer's negative brand engagement adversely affects fellow customers, while positively impacting the firm. In social identity theory, individuals seek to establish their identity by either associating with or 
dissociating from particular social groups (Tajfel, 2010), as outlined. To do so, they attribute positive characteristics to their desired social groups, while assigning negative traits to others. For example, a focal customer may advise a fellow customer to purchase an unflattering outfit to curb his/her own jealousy of the other looking good (Ellis \& Weinstein, 1986). Self-jealousy prevention can thus stem from the focal customer's insecurity that manifests as envious behavior (Guerrero \& Andersen, 1996). If the fellow customer follows the advice, (s)he may later experience cognitive dissonance, tampering with his/her perceived value (Lee \& Li, 2013).

While customer jealousy is discussed in the marketing literature (Ludwig et al., 2017), we extend existing insight by highlighting the focal customer's resolve to reduce his/her own jealousy toward (an)other actor(s) (Clanton, 1996). In this value-based effect, CE's firm-aiding aspect lies in the company making a sale owing to the focal customer's expressed positive brand engagement. However, this is untruthful, as (s)he actually disproves of the brand's particular couture, again revealing his/her sub-optimal moral behavior (Thanvarachorn et al., 2019).

\subsubsection{Firm-aiding, backfired customer misbehavior}

CE's penultimate value-based effect of firm-aiding, backfired customer misbehavior reflects the focal customer's negative brand engagement that transpires positively for fellow customers and the firm (see \#7: Fig. 1). Distributive justice theory addresses the perceived fairness of how stakeholders share rewards/costs (Folger \& Konovsky, 1989), thus aligning with stakeholder theory's multi-actor and moral/ethical facets (Freeman, 1984). For example, a focal customer who maliciously disseminates false, negative brand-related word-of-mouth may in fact strengthen fellow customers' brand-related sentiment (e.g. by stepping up to defend it). Thus, here fellow customers try to rectify a perceived distributive injustice to the firm (Cropanzano et al., 2007).

A focal customer's negative brand engagement can thus motivate fellow customers to display heightened brand-related solidarity or commitment (Tuli et al., 2010), even if they would not have 
re-evaluated their brand relationship and come to heightened brand-related perceived value otherwise. These fellow customers are now also likely to offer more favorable brand referrals (East et al., 2007), contributing to the firm's future sales that can reduce, nullify, or even exceed the focal customer's brand damage.

\subsubsection{Counter-productive customer behavior}

CE's final value-based effect is counter-productive customer behavior, which reflects the focal customer's negative brand engagement that adversely affects fellow customers and the firm (see \#8: Fig. 1; Harris \& Daunt, 2013). As stated, social identity theory predicts actors to attribute positive traits to their desired social groups, but negative ones to others (Tajfel, 2010). For example, a focal customer may malevolently blackmark a brand, thus typecasting it as belonging to an inferior social group and revealing his/her negative engagement (Juric et al., 2016). Consequently, fellow customers' perceived brand value is sub-optimized for those who draw negative inferences from the focal customer's message (Bowden et al., 2017), particularly for new or ambivalent customers. In addition, company value is also compromised (e.g. with fellow customers defecting from the firm).

\section{Discussion and implications}

\subsection{Theoretical implications}

In this paper, we explored positive/negative CE's value-based effects on multiple other actors, which has received scant attention to date. We developed a typology of CE's valuecreating/depleting effects on the particular stakeholder subset of fellow customers and the firm (Curth et al., 2014), which comprehensively covers all CE/value-based combinations for these actors. By classifying positive/negative CE's particular cross-actor effects (Herman \& Miall, 1990), we contribute to the budding literature on connected ecosystem actors' engagement (e.g. Jonas et al., 2018; Alexander et al., 2018). Specifically, our analyses suggest that a customer's brand engagement affects the stakeholders to which (s)he is connected and in turn influences their 
respective ecosystem-based engagement. Therefore, an actor's engagement should not be viewed in isolation, but rather, within the context of his/her networks and key actor interdependencies, thus offering ample frontiers for further research, as discussed further in section 4.3.

We also extend the literature on positive/negative engagement. Though Bowden et al.'s (2017) engagement spill-over effects recognize the potential for a customer's (e.g. positive) engagement with specific brand tenets (e.g. perceived quality) to transfer to others (e.g. price), their analyses highlight positive CE to yield correspondingly (i.e., positively)-valenced effects, and vice versa for negative engagement. Based on stakeholder theory's premise that an actor's engagement can have differing cross-stakeholder effects (Freeman, 1984), we extend existing insight by suggesting that a focal actor's (here, customer's) positive engagement can either enhance or reduce other actors' perceived value, which can differ across stakeholders (and likewise for negative engagement). That is, we identify CE's differentially-valenced value-based outcomes across actors, thereby making an important theoretical contribution to CE research.

\subsection{Practical implications}

This paper also generates significant practical implications. First, we learned from the typology that CE, while exerting a positive effect on one actor (e.g. fellow customer), can simultaneously have a negative effect on another (e.g. the firm; Greenwood, 2007). Therefore, to design effective customer-to-customer interactions in multi-customer contexts, firms need to consider CE's effect on multiple stakeholders. To help optimize CE's value-based cross-actor effects, we thus recommend managers to carefully select customers' interaction partners, including fellow customers, frontline service staff, and support staff (e.g. for high fit in task-related needs/objectives, personality/cultural profiles; Gupta et al., 2018; Marbach et al., 2016).

Second, customers are increasingly proactively contributing to their own brand experience (Sasser et al., 2014; Brodie et al., 2011). Therefore, to what extent should the firm be in control of its customer-to-customer interactions, or customer investments in those interactions (i.e., CE)? 
Given consumers' growing desire for interaction-related control (Harmeling et al., 2017), we advise firms to incorporate personalization or customization options in their customer-to-customer as well as customer-brand interactions (Bleier et al., 2018). We also recommend using customer opt-in/out to stimulate positive CE (Kumar et al., 2014).

Third, though stakeholder theory, philosophically, advocates stakeholders' ethical and moral treatment, as discussed, it has been criticized for failing to accommodate all actors' interests simultaneously (Blattberg, 2004). That is, in practice, it allows for particular (e.g. perceived superior) stakeholder interests to be prioritized, thereby affecting other actors' engagement and perceived value (Greenwood, 2007). We therefore recommend managers to carefully consider particular focal- and fellow customers' engagement and their respective desired value-based outcomes, while consistently ensuring high levels of perceived (e.g. distributive/procedural) justice (e.g. fair VIP vs. regular customer benefits; Mattila et al., 2014).

\subsection{Limitations and further research}

We next identify key limitations inherent in this study, which offer opportunities for further research. First, our purely theoretical analyses render a need for future empirical research to further explore, confirm, or refine our proposed typology, in line with Doty and Glick's (1994) typological falsifiability. For example, qualitative research may be conducted to further explore the main hallmarks, triggers, and outcomes of CE's value-based effects, followed by quantitative research to test these issues (Hair et al., 2017). We also recommend future longitudinal research on CE's cross-actor value-based effects to better understand its evolution over time (see Viswanathan et al., 2017).

Second, while we explored the value-based effects of a focal customer's engagement on fellow customers and the firm, any other focal stakeholder's engagement can be adopted in its stead (e.g. employee, supplier, or media engagement; Freeman, 1984). Consequently, our analyses are replicable by incorporating different actor triads (Keeling et al., 2018), culminating in a similar 
eight-partite typological structure (but with different actors). Researchers may also wish to investigate more extensive actor configurations by expanding the range of investigated stakeholders (Freeman, 2010), and exploring their relevant value-based effects. Here, we identify the following considerations.

One, CE's valence acts as the common denominator for any actor's perceived value-based effects. As outlined, we focused on CE's dual (i.e., positive/negative) valence (Bowden et al., 2017). Two, we used three key actors (i.e., focal customer, fellow customers, firm). For each of these actors, using a dual $\mathrm{CE}$ valence, two value-based (i.e., value-creating/depleting) outcomes exist, yielding $2 * 2 * 2=2^{3}=8$ possible value-based effects. Analogously, the addition of a fourth actor would generate a $2^{4}=16$-partite typology. Thus, using $n$ actors and a dual (positive/negative) $\mathrm{CE}$ valence, $2^{n}$ possible CE value-based effects exist. Further, the addition of engagement's neutral (ambivalent) valence would culminate in a $3^{3}$ (27)-partite typology for three actors (Li et al., 2018), or a $3^{4}(81)$-partite typology for four actors, etc.

Third, while our analyses presume CE's voluntary, free choice-based nature, it is likely to also contain less volitional elements, akin to bounded rationality in economics (Andreassen et al., 2018). Therefore, the focal customer may find him/herself constrained by engagement-hindering factors (e.g. rules; Vargo \& Lusch, 2016). Consequently, further research could fruitfully explore CE's ecosystem-based or situational contingencies, their effects on different actors' engagement/value, or the role of stakeholders' engagement in shaping relevant ecosystem constituents. 


\begin{tabular}{|c|c|c|c|}
\hline Author(s) & Concept & Definition & CE effect and valence \\
\hline \multicolumn{4}{|c|}{ Customer engagement (CE) } \\
\hline $\begin{array}{l}\text { Calder et al. } \\
(2009, \text { p. } 322)\end{array}$ & Engagement & The consumer's “overall experiences of a [media] vehicle.” & $\begin{array}{ll} & \text { Centers on CE's customer-based effect. } \\
\circ & \text { Focuses on positive CE. }\end{array}$ \\
\hline $\begin{array}{l}\text { Brodie et al. } \\
(2011, \text { p. } 258)\end{array}$ & Customer engagement & $\begin{array}{l}\text { "A psychological state that occurs by virtue of interactive, co-creative } \\
\text { customer experiences with a focal agent/object (e.g. a brand) in focal service } \\
\text { relationships." }\end{array}$ & $\begin{array}{l}\text { Centers on CE's customer-based effect. } \\
\circ \quad \text { Focuses on positive CE. }\end{array}$ \\
\hline $\begin{array}{l}\text { Brodie et al. } \\
(2013, \text { p. } 107)\end{array}$ & Consumer engagement & "Specific interactive experiences between consumers and the brand." & $\begin{array}{ll}\circ & \text { Centers on CE's customer-based effect. } \\
\circ & \text { Focuses on positive CE, while allowing negative CE's emergence. }\end{array}$ \\
\hline $\begin{array}{l}\text { Vivek et al. } \\
(2014, \text { p. } 127)\end{array}$ & Customer engagement & $\begin{array}{l}\text { "The intensity of an individual's participation in and connection with an } \\
\text { organization's offerings or organizational activities, which either the } \\
\text { customer or the organization initiate." }\end{array}$ & $\begin{array}{ll} & \text { Centers on CE's customer/brand-based effect. } \\
\circ & \text { Focuses on positive CE. }\end{array}$ \\
\hline $\begin{array}{l}\text { Pansari \& } \\
\text { Kumar }(2017, \\
\text { p. 295) }\end{array}$ & Customer engagement & $\begin{array}{l}\text { "The mechanics of a customer's value addition to the firm, either through } \\
\text { direct or/and indirect contribution." }\end{array}$ & $\begin{array}{ll} & \text { Examines CE's firm-based effect. } \\
\circ & \text { Focuses on positive CE. }\end{array}$ \\
\hline $\begin{array}{l}\text { Hollebeek et } \\
\text { al. }(2014)\end{array}$ & $\begin{array}{l}\text { Customer brand } \\
\text { engagement }\end{array}$ & $\begin{array}{l}\text { "A consumer's positively valenced brand-related cognitive, emotional, and } \\
\text { behavioral activity during or related to customer brand interactions." }\end{array}$ & $\begin{array}{ll} & \text { Centers on CE's customer-based effect. } \\
\circ & \text { Focuses on positive CE. }\end{array}$ \\
\hline $\begin{array}{l}\text { Kumar et al. } \\
(2019, \text { p. } 141)\end{array}$ & Customer engagement & $\begin{array}{l}\text { "A customer's motivationally driven, volitional investment of focal operant } \\
\text { resources (including cognitive, emotional, behavioral and social knowledge } \\
\text { and skills) and operand resources (e.g. equipment) into brand interactions in } \\
\text { service systems" (Hollebeek et al., 2019, p. 167). }\end{array}$ & $\begin{array}{ll} & \text { Centers on CE's customer-based effect. } \\
\circ & \text { Focuses on positive CE, while acknowledging negative CE. }\end{array}$ \\
\hline \multicolumn{4}{|c|}{ Positive/negative CE } \\
\hline $\begin{array}{l}\text { Hollebeek \& } \\
\text { Chen }(2014, \text { p. } \\
66)\end{array}$ & $\begin{array}{l}\text { Positive/negative } \\
\text { brand engagement }\end{array}$ & $\begin{array}{l}\text { "The level of a consumer's "cognitive, emotional and behavioral investment } \\
\text { in specific brand interactions [which can be positive or negative]" } \\
\text { (Hollebeek, 2011, p. 511). }\end{array}$ & $\begin{array}{ll} & \text { Examines CE's effect on the brand. } \\
\circ & \text { Introduces the notion of positive and negative CE. }\end{array}$ \\
\hline $\begin{array}{l}\text { Bowden et al. } \\
(2017, \text { p. } 879)\end{array}$ & $\begin{array}{l}\text { Positive/negative } \\
\text { engagement }\end{array}$ & $\begin{array}{l}\text { "A consumer's cognitive, emotional, and behavioral investments in } \\
\text { interacting with focal objects or agents." }\end{array}$ & $\begin{array}{l}\text { Addresses positive/negative } \mathrm{CE} \text { and their potential co-existence } \\
\text { and spill-over. }\end{array}$ \\
\hline $\begin{array}{l}\text { Heinonen } \\
(2018, \text { p. } 149)\end{array}$ & $\begin{array}{l}\text { Positive/negative } \\
\text { engagement }\end{array}$ & $\begin{array}{l}\text { "Community members' cognitive, emotional, and behavioral investments in } \\
\text { a specific area of interest." }\end{array}$ & $\begin{array}{ll} & \text { Examines CE's community-based effect. } \\
\circ & \text { Addresses positive and negative CE. }\end{array}$ \\
\hline $\begin{array}{l}\text { Li et al. }(2018, \\
\text { p. } 496)\end{array}$ & $\begin{array}{l}\text { Positive, negative, } \\
\text { neutral engagement }\end{array}$ & $\begin{array}{l}\text { "Valence is ... defined as to the individual's evaluation of what is good or } \\
\text { bad." Thus, positive (negative) engagement is what the actor perceives as } \\
\text { good (bad). }\end{array}$ & $\begin{array}{ll} & \text { Engagement object not specified. } \\
\circ & \text { Addresses positive, negative \& neutral engagement. }\end{array}$ \\
\hline
\end{tabular}

Table 1: Customer engagement and related conceptualizations 
Fig. 1: Typology of CE's value-based effects

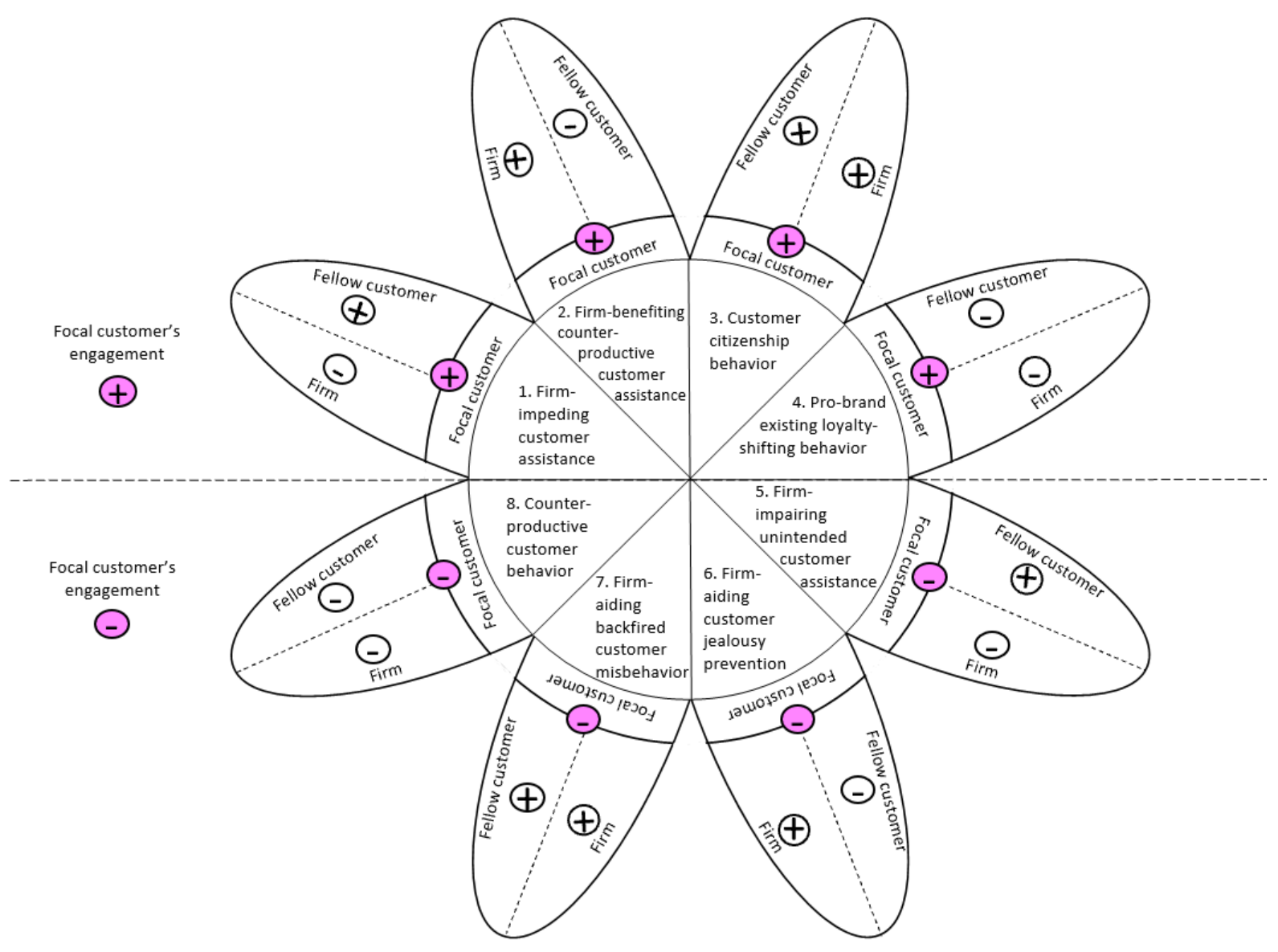




\section{References}

Alexander, M., Jaakkola, E., \& Hollebeek, L. (2018). Zooming out: Actor engagement beyond the dyadic. Journal of Service Management, 29(3), 333-351.

Anderson, J., Oliver, N., Anderson, J. (2001). Collaborative new product development in a multi-customer context: challenges for western auto component suppliers. International Journal of Automotive Technology and Management, 1(2/3), 169-182.

Andiappan, M. \& Dufour, L. (2018). Jealousy at work: A tripartite model. Academy of Management Review, In-press, DOI: https://doi.org/10.5465/amr.2016.0299.

Andreassen, T., Smith, D., Grönquist, Karahasanovic, A. \& Marquez, A. (2018). Service innovation actor engagement: An integrative model. Journal of Services Marketing, 32(1), 95-100.

Baldus, B., Voorhees, C., \& Calantone, R. (2015). Online brand community engagement: Scale development and validation. Journal of Business Research, 68(5), 978-985.

Bartikowski, B., \& Walsh, G. (2011). Investigating mediators between corporate reputation and customer citizenship behaviors. Journal of Business Research, 64, 39-44.

Beckers, S., Risselada, H. \& Verhoef, P. (2014). Customer engagement: A new frontier in customer value management. In: Rust, R. \& Huang, M. (Eds.), Handbook of Service Marketing Research, Edward Elgar, 97-120.

Beckers, S., Van Doorn, J. \& Verhoef, P. (2018). Good, better, engaged? The effect of company-initiated customer engagement on shareholder value. Journal of the Academy of Marketing Science, 46(3), 366-383.

Berry, L. \& Seiders, K. (2008). Serving unfair customers. Business Horizons, 51(1), 29-37.

Blattberg, C. (2004). Welfare: Towards the patriotic corporation. From Pluralist to Patriotic Politics: Putting Practice First. New-York: Oxford University Press, 172-184.

Blau, P. (1964). Exchange and Power in Social Life. New York: Wiley.

Bleier, A., De Keyser, A. \& Verleye, K. (2018). Customer engagement through personalization and customization. In: Palmatier, R., Kumar, V. \& Harmeling, C. (Eds.), Customer Engagement Marketing, Springer, 75-94. 
Bowden, J., Conduit, J., Hollebeek, L., Luoma-Aho, V., \& Solem, B. (2017). Engagement valence duality and spillover effects in online brand communities. Journal of Service Theory and Practice, 27(4), $877-897$.

Brodie, R., Fehrer, J., Hollebeek, L., Jaakkola, E. \& Conduit, J. (2016). Actor engagement: Broadening the conceptual domain. EMAC, Oslo.

Brodie, R., Hollebeek, L., Ilic, A. \& Juric, B. (2011). Customer engagement: Conceptual domain, fundamental propositions \& implications for research in service marketing. Journal of Service Research, 14(3), 252-271.

Brodie, R., Ilic, A., Juric, B. \& Hollebeek, L. (2013). Consumer engagement in a virtual brand community: An exploratory analysis. Journal of Business Research, 66(1), 105-114.

Calder, B., Malthouse, E. \& Schaedel, U. (2009). An empirical study of the relationship between online engagement and advertising effectiveness. Journal of Interactive Marketing, 23, 321-331.

Clanton, G. (1996). A sociology of jealousy. International Journal of Sociology and Social Policy, 16(9/10), 171-189.

Corus, C., \& Ozanne, J. (2012). Stakeholder engagement: Building participatory and deliberative spaces in subsistence markets. Journal of Business Research, 65(12), 1728-1735.

Covell, D. (2005). Attachment, allegiance and a convergent application of stakeholder theory: Assessing the impact of winning on athletic donations in the Ivy League. Sports Marketing Quarterly, 14, $168-176$

Cronin, J. (2016). Retrospective: A cross-sectional test of the effect and conceptualization of service value revisited. Journal of Services Marketing, 30(3), 261-265.

Cropanzano, R., Bowen, D. \& Gilliland, S. (2007). The management of organizational justice. Academy of Management Perspectives, 21(4), 34-48.

Curth, S., Uhrich, S. \& Benkenstein, M. (2014). How commitment to fellow customers affects the customer-firm relationship and customer citizenship behavior. Journal of Services Marketing, 28(2), 147-158. 
Donaldson, T. \& Preston, E. (1995). The stakeholder theory of the corporation: Concepts, evidence, and implications. Academy of Management Review, 20(1), 65-91.

Doty, D. \& Glick, W. (1994). Typologies as a unique form of theory building: Toward improved understanding and modeling. Academy of Management Review, 19(2), 230-251.

East, R., Hammond, K. \& Wright, M. (2007). The relative incidence of positive and negative word of mouth: A multi-category study. International Journal of Research in Marketing, 24(2), 175-184.

Echeverri, P. \& Skålén, P. (2011). Co-creation and co-destruction: A practice-theory based study of interactive value formation. Marketing Theory, 11(3), 351-373.

Edvardsson, B., Tronvol, B. \& Gruber, T. (2011). Expanding understanding of service exchange and value co-creation: A social construction approach. Journal of the Academy of Marketing Science, 39(2), 327-339.

Ekpo, A., Riley, B., Thomas, K., Yvaire, Z., Rosa, G., Henderson, G. \& Munoz, I. (2015). As worlds collide: The role of marketing management in customer-to-customer interactions. Journal of Business Research, 68(1), 119-126.

Ellis, C. \& Weinstein, E. (1986). Jealousy and the social psychology of emotional experience. Journal of Social and Personal Relationships, 3, 337-357.

Elmore, G. \& Huebner, E. (2010). Adolescents' satisfaction with school experiences: Relationships with demographics, attachment relationships, and school engagement behavior. Psychology in Schools, 47(6), 525-537.

Fitzmaurice, J. (2005). Incorporating consumers' motivations into the theory of reasoned action. Psychology \& Marketing, 22(11), 911-929.

Folger, R. \& Konovski, M. (1989). Effects of procedural and distributive justice on reactions to pay rise decisions. Academy of Management Journal, 32(1), 115-130.

Freeman, R. (1984). Strategic Management: A Stakeholder Approach. Boston: Pitman/Ballinger.

Freeman, R. (1999). Divergent stakeholder theory. Academy of Management Review, 24(2), 233-236.

Freeman, R. (2010). Strategic Management: A Stakeholder Approach. Cambridge: Cambridge University. 
Gelbman, A. (2016). Tourism along the geopolitical barrier: Implications of the Holy Land fence. GeoJournal, 81, 671-680.

Greenwood, M. (2007). Stakeholder engagement: Beyond the myth of corporate responsibility. Journal of Business Ethics, 74(4), 315-327.

Grönroos, C. \& Ravald, A. (2011). Service as business logic: Implications for value creation and marketing. Journal of Service Management, 22(1), 5-22.

Guerrero, L. \& Andersen, P. (1996). Jealousy experience and expression in romantic relationships. Handbook of Communication and Emotion, 155-188.

Gupta, S., Pansari, A. \& Kumar, V. (2018). Global customer engagement. Journal of International Marketing, 26(1), 4-29.

Hair, J., Black, W., Babin, B. \& Anderson, R. (2017). Multivariate Data Analysis. Wiley.

Hambrick, D. (1984). Taxonomic approaches to studying strategy: Some conceptual and methodological issues. Journal of Management, 10(1), 27-41.

Harmeling, C., Moffett, J., Arnold, M., \& Carlson, B. (2017). Toward a theory of customer engagement marketing. Journal of the Academy of Marketing Science, 45(3), 312-335.

Harrigan, P., Evers, U., Miles, M., \& Daly, T. (2018). Customer engagement and the relationship between involvement, engagement, self-brand connection and brand usage intent. Journal of Business Research, 88, 388-396.

Harris, L. \& Daunt, K. (2013). Managing customer misbehavior: Challenges and strategies. Journal of Services Marketing, 27(4), 281-293.

Heinonen, K. (2018). Positive and negative valence influencing consumer engagement. Journal of Service Theory and Practice, 28(2), 147-169.

Herman, N. \& Miall, C. (1990). The positive consequences of stigma: Two case studies in mental and physical disability. Qualitative Sociology, 13, 251-269.

Higgins, E. (2012). Regulatory focus theory. In: Van Lange, P., Kruglanski, A. \& Higgins, E. (Eds.), Handbook of Theories of Social Psychology, SAGE, 483-504. 
Hillebrand, B., Driessen, P.H. \& Koll, O. (2015). Stakeholder marketing: Theoretical foundations and required capabilities. Journal of the Academy of Marketing Science, 43(4), 411-428.

Ho, M., Chung, H., Kingshott, R. \& Chiu, C. (2020). Customer engagement, consumption and firm performance in a multi-actor service eco-system: The moderating role of resource integration. Journal of Business Research, DOI: https://doi.org/10.1016/j.jbusres.2020.02.008.

Holbrook, M. (1994). The nature of customer value: An axiology of services in the consumption experience, In: Rust, R. \& Oliver, R. (Eds.), Service Quality, Thousand-Oaks: SAGE, 21-71.

Hollebeek, L., Brodie, R. \& Conduit, J. (2016). Strategic drivers, anticipated \& unanticipated outcomes of customer engagement. Journal of Marketing Management, 32(5-6), 393-398.

Hollebeek, L. \& Chen, T. (2014). Exploring positively- vs. negatively-valenced brand engagement: A conceptual model. Journal of Product \& Brand Management, 23(1), 62-74.

Hollebeek, L., Glynn, M. \& Brodie, R. (2014). Consumer brand engagement in social media: Conceptualization, scale development and validation. Journal of Interactive Marketing, 28(2), 149165.

Hollebeek, L., Srivastava, R.K., \& Chen, T. (2019). S-D logic-informed customer engagement: Integrative framework, revised fundamental propositions, and application to CRM. Journal of the Academy of Marketing Science, 47(1), 161-185.

Hult, G.T., Mena, J., Ferrell, O. \& Ferrell, L. (2011). Stakeholder marketing: A definition and conceptual framework. AMS Review, 1(1), 44-65.

Hunt, S. (1983). General theories and the fundamental explananda of marketing. Journal of Marketing, 47(4), 9-17.

Islam, J., Rasool, A., Khan, I. \& Rahman, Z. (2019). Customer engagement in the service context: An empirical investigation of the construct, its antecedents and consequences. Journal of Retailing \& Consumer Services, 50, 277-285.

Jonas, J., Boha, J., Sörhammar, D., \& Moeslein, K. (2018). Stakeholder engagement in intra- and interorganizational innovation: Exploring antecedents of engagement in service ecosystems. Journal of Service Management, 29(3), 399-421. 
Juric, B., Smith, S., \& Wilks, G. (2016). Negative customer brand engagement. In: Customer Engagement: Contemporary Issues and Challenges. Singapore: Routledge, 272-286.

Keeling, D., Laing, A., \& De Ruyter, K. (2018). Evolving roles and structures of triadic engagement in healthcare. Journal of Service Management, 29(3), 352-377.

Keller, K. \& Sood, S. (2003). Brand equity dilution. MIT Sloan Management Review, 45(1), 12-15.

Kim, A., Moon, J. \& Shin, J. (2019). Justice perceptions, perceived insider status, and gossip at work: A social exchange perspective. Journal of Business Research, 97(Apr), 30-42.

Kozinets, R. (1999). E-tribalized marketing? The strategic implications of virtual communities of consumption. European Management Journal, 17(3), 252-264.

Kumar, V., Aksoy, L., Donkers, B., Venkatesan, R., Wiesel, T., \& Tillmanns, S. (2010). Undervalued or overvalued customers: Capturing total customer engagement value. Journal of Service Research, 13(3), 297-310.

Kumar, V., \& Pansari, A. (2016). Competitive advantage through engagement. Journal of Marketing Research, 53(4), 497-514.

Kumar, V., Rajan, B., Gupta, S., \& Dalla Pozza, I. (2019). Customer engagement in service. Journal of the Academy of Marketing Science, 47(1), 138-160.

Kumar, V., Zhang, X. \& Luo, A. (2014). Modeling customer opt-in and opt-out in a permission-based marketing context. Journal of Marketing Research, 51(4), 403-419.

Lam, S., Aherane, M., Hu, Y. \& Schillewaert, N. (2010). Resistance to brand switching when a radically new brand is introduced: A social identity theory perspective. Journal of Marketing, 74(6), 128.

Lee, L.Y. \& Li, L.Y. (2013). A study on effect of cognitive dissonance on consumption value, anticipated satisfaction and word-of-mouth communication. Journal of Global Business Management, 9(2), 71-79.

Leroi-Werelds, S. (2019). An update on customer value: State of the art, revised typology, and research agenda. Journal of Service Management, 30(5), 650-680.

Li, P., Juric, B., \& Brodie, R. (2018). Actor engagement valence: Conceptual foundations, propositions and research directions. Journal of Service Management, 29(3), 491-516. 
Libai, B., Bolton, R., Buegel, M., De Ruyter, K., Gotz, O., Risselada, H. \& Stephen, A. (2010). Customerto-customer interactions: Broadening the scope of word of mouth research. Journal of Service Research, 13(3), 267-282.

Ludwig, N., Barnes, D., \& Gouthier, M. (2017). Observing delightful experiences of other customers: The double-edged sword of jealousy and joy. Journal of Service Theory and Practice, 27(1), 145-163.

Marbach, J., Lages, C.R. \& Nunan, D. (2016). Who are you and what do you value? Investigating the role of personality traits and customer-perceived value in online customer engagement. Journal of Marketing Management, 32(5-6), 502-525.

Mattila, A., Hanks, L., \& Wang, C. (2014). Others' service experiences: Emotions, perceived justice, and behavior. European Journal of Marketing, 48(3/4), 552-571.

Mitchell, S. \& Clark, M.K. (2019). Reconceptualising product life-cycle theory as stakeholder engagement with non-profit organisations. Journal of Marketing Management, 35(1-2), 13-39.

MSI - Marketing Science Institute (2010). Research Priorities.

MSI - Marketing Science Institute (2018). Research Priorities.

O'Connor, E. \& Crowley-Henry, M. (2019). Exploring the relationship between exclusive talent management, perceived organizational justice and employee engagement: Bridging the literature. Journal of Business Ethics, 156(4), 903-917.

Pansari, A. \& Kumar, V. (2017). Customer engagement: The construct, antecedents, and consequences. Journal of the Academy of Marketing Science, 45(3), 294-311.

Peters, L., Lobler, H., Breidbach, C., Smith, S., Sorhammar, D. \& Varey, R. (2014). Theorizing about resource integration though S-D logic. Marketing Theory, 14(3), 249-268.

Porter, M. (1980). Competitive Strategy. New York: Free Press.

Plutchik, R. (1980). Plutchik's wheel of emotions. Accessed (Dec 2, 2019) at: https://www.researchgate.net/publication/234005320_Discovering_Basic_Emotion_Sets_via_Se mantic_Clustering_on_a_TwitterCorpus/figures? $10=1$.

Roy, S., Balaji, M., Soutar, G., Lassar, W., \& Rajat, R. (2018). Customer engagement behavior in individualistic and collectivistic markets. Journal of Business Research, 86(May), 281-290. 
Santoro, S., Bertoldi, B., Giachino, C. \& Candelo, E. (2018). Exploring the relationship between entrepreneurial resilience and success: The moderating role of stakeholders' engagement. Journal of Business Research. In-press, DOI: https://doi.org/10.1016/j.jbusres.2018.11.052.

Sasser, S., Kilgour, M. \& Beck, D. (2014). Marketing in an interactive world: The evolving nature of communication processes using social media. In: Lertwachera, K. \& Ayanso, A., Harnessing the Power of Social Media and Web Analytics, New York: IGI-Global, 29-52.

Slater, S. (1997). Developing a customer value-based theory of the firm. Journal of the Academy of Marketing Science, 25(2), 162-167.

Smith, A. (2013). The value co-destruction process: A customer resource perspective. European Journal of Marketing, 47(11-12): 1889-1909.

Sreejesh, S., Sarkar, J., Sarkar, A., Eshgi,A \& Anusree, M. (2017). The impact of other customer perception on consumer-brand relationships. Journal of Service Theory \& Practice, 28(2), 130-146.

Tajfel, H. (2010). Social Identity and Intergroup Relations, Cambridge University Press.

Thanvarachorn, A., Alexander, M. \& Doherty, A. (2019). Inauthentic engagement. International Research Symposium on Advancing Service Research and Practice, June.

Tombs, A. \& McColl-Kennedy, J. (2003). Social servicescape conceptual model. Marketing Theory, 3(4), 447-475.

Tuli, K., Bharadwaj, S. \& Kohli, A. (2010). Ties that bind: The impact of multiple types of ties with a customer on sales growth and sales volatility. Journal of Marketing Research, 47(Feb), 36-50.

Vargo, S. \& Akaka, M. (2012). Value cocreation and service systems (re)formation: A service ecosystems view. Service Science, 4(3), 2017-2217.

Vargo, S., \& Lusch, R. (2016). Institutions and axioms: An extension and update of service-dominant logic. Journal of the Academy of Marketing Science, 44(1), 5-23.

Verleye, K., Gemmel, P. \& Rangarajan, D. (2014). Managing engagement behaviors in a network of customers and stakeholders: Evidence from the nursing home sector. Journal of Service Research, 17(1), 68-84. 
Viswanathan, V., Malthouse, E., Kim, S.J., \& Xie, W. (2017). The dynamics of consumer engagement with mobile technologies. Service Science, 9(1), 36-49.

Vivek, S., Beatty, S., Dalela, V., \& Morgan, R. (2014). A generalized multidimensional scale for measuring customer engagement. Journal of Marketing Theory and Practice, 22(4), 401-420.

Woodruff, R. (1997). Customer value: The next source for competitive advantage. Journal of the Academy of Marketing Science, 25, 139-164.

Wu, J. \& Rangaswamy, A. (2003). A fuzzy set model of search and consideration with an application to an online market. Marketing Science, 22(3), 411-434.

Xie, C., Bagozzi, R., \& Troye, S. (2008). Trying to prosume: Toward a theory of consumers as co-creators of value. Journal of the Academy of Marketing Science, 36(1), 109-122.

Zeithaml, V. (1988). Consumer perceptions of price, quality, and value: A means-end model and synthesis of the evidence. Journal of Marketing, 52(3), 2-22. 